\title{
Erratum
}

\section{Development, larval voracity, and greenhouse releases of Stethorus punctillum (Coleoptera: Coccinellidae)'}

\author{
DA Raworth ${ }^{2}$ \\ Agriculture and Agri-Food Canada, Pacific Agri-Food Research Centre, \\ PO Box 1000-6947, Highway No. 7, Agassiz, British Columbia, Canada V0M 1A0
}

The Canadian Entomologist 133: 895 (2001)

In volume 133 , issue 5 , the first line on $\mathrm{p} 722$, the duration was from "egg to adult" and not "egg hatch to adult". In context, it shoud read: Duration from egg to adult was $217.1 \pm 0.1^{\circ} \mathrm{d}$ above $11.6^{\circ} \mathrm{C}$.

\footnotetext{
1 Ref: The Canadian Entomologist 133: 721-724 (2001).

2 E-mail: raworthd@em.agr.ca.
} 